\title{
Toward a Participatory Model of Peace Education: The Case of Timor-Leste
}

\author{
Pantea Beigi \\ The University of Queensland
}

\begin{abstract}
This paper examines the effectiveness of participatory learning in post-conflict environments. It is a case study of post-conflict peace education in Timor-Leste. Using a set of qualitative methods, the study reveals the barriers as well as advantages in adopting participatory models of learning in peace education. It argues that the benefits of adopting participatory learning outweigh the risks. Thus providing an account of the effectiveness of participatory learning as post-conflict peace education in Timor-Leste.
\end{abstract}

\section{Introduction}

In recent years, educators and practitioners seeking to address the challenging nature of worldwide conflicts have adopted an array of innovative approaches to peace education. Dance 4 Peace, a global peace education organization, relies on creative movement to transform communities. It operates in Mindanao in the Philippines, where a protracted armed conflict between several religious and tribal groups has claimed countless lives over many decades and has resulted in the displacement of thousands of individuals and families. On the other hand, the Peace Corps focuses on service to foster goodwill and understanding between American volunteers and host communities across the globe. Several Peace Corps volunteers are currently serving in the Fiji Islands to empower women by creating income generating initiatives such as a women's village sewing club.

Securing a safe environment to facilitate creative movement following a violent event in Mindanao requires both physical and emotional considerations. Similarly, empowering women in a Fijian village where men have traditionally dominated private and public spaces may become a source of conflict rather than peace in the community. These challenges pose important questions regarding context specific learning frameworks in conflict prone environments. As the nature of conflicts has continued to shift and change in recent history, so have the response approaches to postconflict reconstruction. Healing communities that have been torn by intra and inter-state conflict while rebuilding institutions and infrastructure: roads, schools, and medical facilities and the like is not an easy task. Questions of identity, representation, and the reemergence of conflict are often at the forefront of reconstruction projects, and some communities have fallen right back into unrest after a seeming end to violence. Vast resources are often invested in seeking the expert advice and knowledge of consultants who advise on best practices for moving forward, once a conflict has come to an end. Yet, in many instances patterns of violence and instability re-surface particularly among the younger generations in postconflict environments.

In the case of Timor-Leste, the considerations for creating conducive learning environments may not require many physical safety precautions as the country has, since its independence in 2002 experienced relative calm and stability. The psychological and emotional considerations however do prove vital in the learning process.

This paper is organized in three sections. The first section considers the educational barriers faced by Timorese youth. The second section, which draws from from focus groups, workshops, evaluations, and semistructured interviews with students and educators who partook in a yearlong participatory peace education program in Timor-Leste, provides a case study of participatory learning as peace education in TimorLeste. The third and concluding section provides, on the basis of that case study, an argument for the effectiveness of participatory learning in post-conflict peace education.

For the purpose of this study, 'participatory' refers to a learning model that relies on peer teaching methods, including learners' contributions to group knowledge and decision making over educational material and modes of teaching.

\section{Educational Barriers Faced by Timorese Youth}

Firstly, it is important to note that Timor-Leste has a very young demographic. As of $2010,52.3 \%$ of the population was under the age of 20 [1]. In TimorLeste, helping children and youth to understand the many facets of a community's painful past becomes an integral component of successful peace education programming. A 2013 study published in the World 
Bank Economic Review on the short and long-term effects of violence on education in Timor-Leste suggests there is "evidence of a substantial loss of human capital among boys in Timor-Leste who were exposed to peaks of violence during the 25-year long conflict"[2]. In particular, due to inequitable gender roles and power dynamics, many young girls continue to remain vulnerable in their communities as they did during the Indonesian occupation.

Timorese youth and young professionals wishing to engage with local communities to create and promote peace, stability and prosperity in their nation are faced with enormous challenges. These challenges include insufficient access to local training and education, as well as a lack of access and exposure to collaborative forums with other youth in the region. Generations of colonial rule followed by foreign occupation have deprived young Timorese women and men of the ability to develop the skills and knowledge necessary to lead peaceful and prosperous communities. These setbacks have placed them at a disadvantage to other youths in the Asia-Pacific region.

As Timor-Leste moves beyond its history of conflict, disarming the armed conscience of its youth population and creating gender equitable societies becomes an important challenge. Addressing this challenge requires both theoretical and practical applications of non-violent problem solving at the community level. While significant dollar amounts in international aid and national projects have been focused on development in Timor-Leste, the remnants of decades of conflict are still visible throughout different layers of society, including in the education sector. Aside from lack of facilities, material, and adequate training for teachers, it is often the case that upon entering school, the language of instruction is different from the language students speak at home. This in itself adds significant complications to an already disadvantaged learning environment. Compounded with poverty, lack of industry, and high unemployment rates, Timorese youth face great challenges in engaging with tangible means to positively transform their lives.

\section{Case Study: Participatory Learning as Peace Education in Timor-Leste}

In November 2011, with the sponsorship of then Timorese President José Ramos-Horta, over 35 Timorese male and female members of the Rotaract Club of Dili [3] completed a two-day teacher training course in Dili. The Rotaractors were trained to teach a peace and conflict resolution curriculum, which had been written by the PeaceJam Foundation [4], to two different age groups: 11 to 14 years and 14 to 24 years. The training was conducted in English with only occasional Tetun translations, as all Timorese Rotaractors participating in the training were fluent in English. The evaluations collected from Rotaract members at the end of the training course revealed that, on the whole, they found the training very valuable but not entirely relevant to life in the villages across Timor-Leste. They indicated a strong interest in undergoing further training that was more specific to experiences in Timor-Leste.

Although, access to global education and information has accelerated at an unprecedented rate since the information revolution of the 1990 s, scholars have long argued on the importance of culturally relevant educational curricula. As described by H.B. Danesh, peace education in particular is believed to be "based on the concept that peace is, at once, a psychological, social, political, ethical and spiritual state with its expressions in intrapersonal, interpersonal, intergroup, international, and global areas of human life" further suggesting "that all human states of being, including peace, are shaped by our worldview_our view of reality, human nature, purpose of life and human relationships"[5]. Therefor an effective peace education curriculum must encompass the aforementioned concepts of cultural awareness.

Focusing on two core principles of fostering positive change and instilling self-efficacy as indicators for assessing the program amongst learners, an adapted peace education curriculum was created. Using a participatory model of learning the adapted curriculum was informed by the shared knowledge of Timorese Rotaractors and it has since evolved into a local model that now guides theoretical discussions and practical applications of peace and conflict resolution in local communities where Rotaractors live and volunteer.

In 2012, through a series of Skype sessions the Timorese Rotaractors were led in exploring many important facets of conflict resolution such as gender equality, problem solving techniques and leadership skills. The Skype lessons were context specific, taking into account the socio-economic and geopolitical factors concerning the everyday lived experiences of Timorese communities. During this year-long exchange with the Rotaractors, and while using distance learning as well as occasional on-site trainings, many barriers and advantages to adopting a participatory model were identified and closely examined.

For outsiders, it is expected that there will be challenges in gaining the acceptance of the host community, in particular those participating in the educational programs. It is also common for conflicts to re-emerge in participatory learning environments in post-conflict communities, where the learning space is used as a platform for personal or political gain. In such an instance, the learning space becomes politicized and creates a risk for some participants to experience trauma and become re-victimized. While variations of all of these barriers and risks were evident, all were minimized and almost rarely experienced by the first quarter of the program. 
The more the group was encouraged to share and add their knowledge to the adapted curriculum the more they appeared to take ownership of the learning process and thus no longer viewed the educator as an 'outsider'. As skill and knowledge levels increased in peer-mediation and conflict resolution, group members established self-governed boundaries that protected the learning space. These measures have been essential in creating equal opportunity for all members to speak, contribute, and guide during discussions.

\section{Benefits of Adopting Participatory Models of Learning in Post-Conflict Peace Education}

The adopted model of participatory peace education culminated in a youth peace and leadership conference in May 2013. Up to 21 Australian Interact and Rotary Youth Exchange students and 40 Timorese male and female students participated. The conference adopted PeaceJam's model, which comprised workshop sessions, team building exercises, keynote addresses and a community service project concerning global issues such as ending violence against women, alleviating poverty, controlling spread of disease and access to education. The students were placed into groups of five to six and one Timorese Rotaract member led each group. This in itself was a significant step forward, as it is extremely rare for Timorese youth (particularly young women) to be given the opportunity to lead or mentor foreigners. The Timorese Rotaractors displayed high levels of confidence in their ability to host and mentor their foreign counterparts (which comprised Australian students and exchange students from Japan, Brazil, Peru, Canada, Belgium, Finland, Germany, Switzerland, Denmark and France), and facilitated meaningful dialogue within their groups.

Evaluations conducted at the end of the conference indicated that the Timorese Rotaractors had made a positive impact in their respective groups. For instance, a Brazilian exchange student studying in Australia said that learning about the experiences of the Timorese students made her more grateful for her privileges and she was inspired to volunteer and participate more in community activities. Equally, some Timorese students were particularly moved by the stories shared by Australian Northern Territory students about the challenges facing indigenous communities there. According to the Rotaractors, these powerful exchanges have made a lasting impression on their lives. Most importantly, all the Timorese Rotaractors said they wanted to share the skills they had learnt over the course of the program and at the conference with their villages. Some even said they wanted to organise similar courses for school students in their localities. Another resounding theme was the Rotaractors' strong desire for further training on peace education, conflict resolution and leadership, together with further opportunities to collaborate with foreign students.

Semi-structured interviews with stake holders and members of the host community revealed that on the whole, the program was believed to have made a positive impact on the lives of many young Timorese and their communities. At the time of publication, the Timorese Rotaractors are continuing to engage in a series of service learning projects in their villages where they are applying the culturally appropriate conflict resolution and leadership skills they have acquired. Establishing post-conflict practices and peace education curricula, which are informed by those that have experienced the conflict, has served a significant role in maximizing learning and minimizing risks in adopting a participatory model of peace education.

Based on the two indicators of fostering positive change and instilling self-efficacy amongst Timorese youth and young professionals, using a participatory model of learning has proven to be an effective tool for peace education in Timor-Leste. It is suggested that greater focus be placed on research and funding for implementation, monitoring, and evaluation of participatory programs for youth development and peace education in Timor-Leste.

\section{References}

[1] National Statistics Directorate and United Nations Population Fund. (2010) 'Population and Housing Census of Timor-Leste',http://www.mof.gov.t1/wp-content/uploads/ 2011/06/Publication-2-English-Web.pdf (25 May 2013).

[2] Justino, P., Leone, M., and Paola Salardi (2013)‘Shortand Long-Term Impact of Violence on Education: The Case of Timor Leste',World Bank Econ Review.

[3] Rotaract is a Rotary-sponsored service club for young men and women ages 18 to 30 . All Rotaract efforts begin at the local, grassroots level, with members addressing their communities' physical and social needs while promoting international understanding and peace through a framework of friendship and service.

[4] PeaceJam is an international education program, which seeks to create young leaders committed to positive change in themselves, their communities and the world through the inspiration of Nobel Peace Laureates who pass on the spirit, skills, and wisdom they embody.

[5] H. B. Danesh (2006) 'Towards an integrative theory of peace education', Journal of Peace Education (3) 1, pp. 5578.

[6] Interact is Rotary International's service club for young people ages 12 to 18 . It is based on developing leadership skills and personal integrity through demonstrating respect for others, individual responsibility, international understanding and goodwill. 